\title{
PENDIDIKAN PRA NIKAH; IKHTIAR MEMBENTUK KELUARGA SAKINAH
}

\author{
Amirah Mawarid ${ }^{1}$ \\ ${ }^{* 1}$ Pendidikan Agama Islam Fakultas Agama Islam| Unismuh Makassar \\ Amirahmawardi@unismuh.ac.id
}

\begin{abstract}
ABSTRAK
Tulisan Pendidikan Pra Nikah; Ikhtiar Membentuk Keluarga Sakinah ini disebabkan oleh adanya angka perceraian yang sangat tinggi akibat dari pernikahan usia dini yang belum memahami urgensi dan fungsi keluarga. Tujuan dari penulisan ini adalah untuk mengedekuasi anak usia pra nikah agar lebih siap baik secara mental maupun pengetahuan. Jenis penelitian ini adalah kepustakaan, di mana penulis malakukan penelusuran terhadap beberapa literatur yang terkait. Dengan demikian, maka sumber data dari tulisan ini adalah buku-buku ilmiah yang diterbitkan dengan maksud dijadikan sumber referensi. Hasil penelitian ini menunjukkan bahwa urgensi keluarga, fungsi dan peran keluarga, tugas dan tanggungjawab keluarga, ciri-ciri keluarga, serta faktor dan prinsip keluarga sakinah perlu diberikan kepada anak usia pra nikah agar kelak menjadi keluarga yang sakinah mawaddah wa rahmah.
\end{abstract}

Kata Kunci: Pendidikan Pra Nikah dan Keluarga Sakinah

\begin{abstract}
Pre-Marriage Writing Paper; Ikhtiar Forming a Sakinah Family was caused by the very high divorce rate resulting from an early marriage that has not understood the urgency and function of the family. The purpose of this paper was to educated pre-married age children to be better prepared both mentally and knowledge. This type of research was a literature, in which the authors trace a number of related literature. Thus, the data sources of this paper are scientific books published with the intention of being a reference source. The results of this study indicated that family urgency, family functions and roles, family duties and responsibilities, family characteristics, and sakinah family principles and factors need to be given to pre married children in order to become a sakinah mawaddah wa rahmah family.
\end{abstract}

Keywords: Pre-marriage Education and Sakinah Family 


\section{PENDAHULUAN}

Menurut undang-undang RI nomor 1 tahun 1974 pengertian dan tujuan perkawinan terdapat dalam satu pasal, yaitu bab 1 pasal 1 menetapkan bahwa "perkawinan adalah ikatan lahir batin antara seorang pria dengan seorang wanita sebagai suami istri dengan tujuan membentuk rumah tangga, keluarga yang bahagia dan kekal berdasarkan Ketuhanan Yang Maha Esa". Dengan demikian jelas bahwa diantara tujuan pernikahan adalah membentuk sebuah rumah tangga yang sakinah, mawaddah dan warahmah.

Sebuah masyarakat di negara manapun adalah kumpulan dari beberapa keluarga. Apabila keluarga kukuh, maka masyarakat akan bersih dan kukuh. Namun apabila rapuh, maka rapuhlah masyarakat. Menikah memang tidaklah sullit, tetapi membangun keluarga sakinah bukan sesuatu yang mudah. Pekerjaan membangun, pertama harus didahului dengan adanya gambar yang merupakan konsep dari bangunan yang diinginkan. Demikian juga membangun keluarga sakinah, terlebih dahulu orang harus memiliki konsep tentang keluarga sakinah.

Keluarga adalah satu unit orang-orang yang selalu berhubungan, biasanya hidup bersama dalam bagian hidup mereka, bekerja bersama untuk memuaskan kebutuhan mereka dan saling berhubungan untuk memuaskan keinginannya. Keluarga dimulai dengan sepasang suami istri dan menjadi lengkap dengan hadirnya anak. Keluarga yang terdiri dari sepasang suami istri dan anaknya disebut keluarga inti. Keluarga merupakan kesatuan yang terkecil dalam masyarakat dan merupakan suatu lembaga yang sangat penting dalam pembangunan dan perkembangan suatu negara. Di negara kita ada yang disebut dengan istilah keluarga besar yaitu semua anggota keluarga ada kaitannya satu sama lain karena nenek moyang yang sama, atau karena perkawinan, dan bisa juga mereka saling mempengaruhi dalam pembentukan sikap dan perkembangan pribadi anggota keluarga.

\section{METODE PENELITIAN}

Metode yang digunakan dalam penelitian ini adalah metode deskriptif 
kualitatif. Penelitian deskriptif ekonomis dan psiko sosial. Masalah merupakan penelitian yang bertujuan salah satu anggota merupakan masalah menggambarkan suatu kondisi terkait. bersama seluruh anggota keluarga. 4) Adapun sumber data dari tulisan ini Fungsi Rekreatif, di mana keluarga adalah buku-buku ilmiah yang diterbitkan dengan maksud dijadikan sumber referensi

\section{HASIL DAN PEMBAHASAN PENELITIAN}

Masyarakat adalah cerminan kondisi keluarga, jika keluarga sehat berarti masyarakatnya juga sehat. Jika keluarga bahagia berarti masyarakatnya juga bahagia. Selain sebagai penentu kondisi masyarakat tersebut, keluarga juga mempunyai beberapa fungsi lain dari sudut pandang yang berbeda, yaitu 1) Fungsi Reproduksi, di mana keluarga mempunyai fungsi produksi, karena keluarga dapat menghasilkan keturunan secara sah. 2) Fungsi Ekonomi, di mana kesatuan ekonomi mandiri, anggota keluarga mendapatkan dan membelanjakan harta untuk memenuhi keperluan. 3) Fungsi Protektif, di mana keluarga harus senantiasa melindungi anggotanya dari ancaman fisik, merupakan pusat rekreasi bagi para anggotanya. Kejenuhan dapat dihilangkan ketika sedang berkumpul atau bergurau dengan anggota keluarganya. 5) Fungsi Afektif, di mana keluarga memberikan kasih sayang, pengertian dan tolomg menolong diantara anggota keluarganya, baik antara orang tu terhadap anak-anaknya maupun sebaliknya. 6) Fungsi Edukatif, di mana keluarga memberikan pendidikan kepada anggotanya, terutama kepada anak-anak agar anak-anak tumbuh menjadi anak yang mempunyai budi pekerti luhur. Sehingga keluarga merupakan tempat pendidikan yang paling utama.

Selain fungsi, lembaga keluarga juga memiliki peran yang sangat penting dalam pembentukan karakter dan kepribadian seseorang, karena keluarga merupakan tempat pendidikan yang pertama dan utama bagi anak. Perilaku seseorang di luar lingkungan akan mencerminkan bagaimana kehidupan dalam 
keluarganya, oleh karena itu baik buruknya moral suatu bangsa akan sangat bergantung pada bagaimana pendidikan diterapkan di keluarga. Jika individu dalam keluarga tumbuh dan berkembang dalam suasana yang harmonis dan saling menghargai, maka akan melahirkan generasi yang baik, sebaliknya jika dalam keluarga sering terjadi pertengkaran, maka akan tumbuh generasi yang rapuh. Sebagai contoh, percakapan dalam keluarga, apabila dalam keluarga selalu menggunakan kata-kata yang benar dan menyentuh hati (qaulan sadiidan), perkataan yang patut (qaulan ma'ruufan), perkataan yang mulia (qaulan kariiman), maka anak yang pada usia 0 bulan sampai 1 tahun merekam suasana di lingkungan terdekatnya, usia 1-5 tahun meniru apa yang dikatakan, usia 5-12 tahun meniru apa yang dilakuka, usia 12-18 tahun mencoba apa yang ia rekam, ia dengar, ia lihat, maka akan terbentuklah apa yang disebut perilaku. Di sinilah letak pentingnya setiap keluarga muslim meniti di atas sunnah untuk menggapai keluarga sakinah.

\section{Tugas dan Tanggungjawab}

\section{Keluarga}

Tugas utama keluarga adalah untuk memenuhi kebutuhan jasmani, rohani dan sosial semua anggotanya mencakup pemeliharaan dan perawatan anak-anak membimbing perkembangan pribadi, serta mendidik agar mereka hidup bahagia. Dua komponen yang pertama yakni ayah dan ibu dapat dikatakan sebagai komponen yang sangat menetukan kehidupan anak, karena mereka merupakan pengasuh dan pendidik yang pertama dan utama bagi anak dalam lingkungan keluarga baik karena alasan biologis maupun psikologis. Bagi keluarga anak merupakan anugerah dari Allah SWT yang mempunyai dua potensial yaitu bisa menjadi baik dan bisa pula menjadi buruk. Baik buruknya anak sangat erat kaitannya dengan pendidikan yang diberikan oleh kedua orang tuanya.

Beberapa tanggung jawab yang harus dipenuhi oleh orangg tua terhadap anaknya antara lain merawat dengan penuh kasih sayang, memberikan nafkah yang baik dan halal, serta mendidik dengan bak dan benar. Ketiga kewajiban dan tanggung 
jawab tersebut hendaklah dilakukan secara konsekuen dan harus dipandang sebagai satu kesatuan yang tidak terpisahkan, serta dilaksanakan secara bersamaan dan berkesinambungan, mulai sejak anak berada dalam kandungan ibu sampai benar-benar dewasa.

Deskripsi tugas dan tanggung jawab keluarga tersebut, berdasarkan pada pengertian keluarga sakinah. Menurut kaidah bahasa Indonesia, sakinah mempunyai arti kedamaian, ketentraman, ketenangan, kebahagiaan. Jadi keluarga sakinah mengandung makna keluarga yang diliputi rasa damai, tentram, juga. Jadi keluarga sakinah adalah kondisi yang sangat ideal dalam kehidupan keluarga.

Allah SWT berfirman dalam Qs.Ar-Ruum ayat 21, sebagaimana terjemahannya sebagai berikut:

Dan di antara tanda-tanda kekuasaanNya ialah Dia menciptakan untukmu isteri-isteri dari jenismu sendiri, supaya kamu cenderung dan merasa tenteram kepadanya, dan dijadikanNya diantaramu rasa kasih dan sayang. Sesungguhnya pada yang demikian itu benar-benar terdapat tanda-tanda bagi kaum yang berfikir.
Merujuk pada ayat tersebut, maka keluarga sakinah adalah keluarga yang penuh kasih sayang diantara anggota keluarganya karena mereka saling memahami watak, mengenal jejak sesama anggota keluarga, saling tolong menolong dan saling menjamin rasa aman dan ekonomi. Dengan demikian, keluarga sakinah ialah kondisi sebuah keluarga yang sangat ideal yang terbentuk berlandaskan AlQuran dan Sunnah untuk mencapai kebahagiaan di dunia dan di akhirat.

\section{Ciri-Ciri Keluarga Sakinah}

Pada dasarnya, keluarga
sakinah sukar diukur karena
merupakan satu perkara yang abstrak
dan hanya boleh ditentukan oleh
pasangan yang berumahtangga.
Namun, terdapat beberapa ciri-ciri
keluarga sakinah, diantaranya:

a. Rumah Tangga didirikan berlandaskan Al-quran dan sunnah Asas yang paling penting dalam pembentukan sebuah keluarga sakinah ialah rumah tangga yang dibina atas landasan taqwa, berpandukan Al-Quran dan Sunnah dan bukannya atas dasar cinta semata-mata. Ia menjadi panduan 
kepada suami istri sekiranya menghadapi perbagai masalah yang akan timbul dalam kehidupan berumahtangga.

Firman Allah SWT dalam Surat AnNisa' ayat 59 yang terjemahnya sebagai berikut:

Kemudian jika kamu selisih faham/pendapat tentang sesuatu, maka kembalilah kepada Allah (AlQuran) dan Rasulullah (Sunnah)

b. Rumah Tangga Berasaskan Kasih Sayang (Mawaddah Warahmah) Tanpa 'al-mawaddah' dan 'alRahmah', masyarakat tidak akan dapat hidup dengan tenang dan aman terutamanya dalam institusi kekeluargaan. Dua perkara ini sangat-sangat diperlukan kerana sifat kasih sayang yang wujud dalam sebuah rumah tangga dapat melahirkan sebuah masyarakat yang bahagia, saling menghormati, saling mempercayai dan tolong-menolong. Tanpa kasih sayang, perkawinan akan hancur, kebahagiaan hanya akan menjadi angan-angan saja.

c. Mengetahui Peraturan Berumah tangga

Setiap keluarga seharusnya mempunyai peraturan yang patut dipatuhi oleh setiap ahlinya yang mana seorang istri wajib taat kepada suami dengan tidak keluar rumah melainkan setelah mendapat izin, tidak menyanggah pendapat suami walaupun si istri merasakan dirinya betul selama suami tidak melanggar syariat, dan tidak menceritakan hal rumahtangga kepada orang lain. Anak pula wajib taat kepada kedua orangtuanya selama perintah keduanya tidak bertentangan dengan larangan Allah.

Lain pula peranan sebagai seorang suami. Suami merupakan ketua keluarga dan mempunyai tanggung jawab memastikan setiap ahli keluarganya untuk mematuhi peraturan dan memainkan peranan masing-masing dalam keluarga supaya sebuah keluarga sakinah dapat dibentuk.

Firman Allah SWT dalam Surat AnNisa ayat 34 yang terjemahannya sebagai berikut:

Kaum laki-laki itu adalah pemimpin bagi kaum wanita, oleh Karena Allah Telah melebihkan sebahagian mereka (laki-laki) atas sebahagian yang lain (wanita), dan Karena mereka (laki-laki) Telah 
menafkahkan sebagian dari harta mereka. sebab itu Maka wanita yang saleh, ialah yang taat kepada Allah lagi memelihara diri ketika suaminya tidak ada, oleh Karena Allah Telah memelihara (mereka)[290]. wanita-wanita yang kamu khawatirkan nusyuznya, Maka nasehatilah mereka dan pisahkanlah mereka di tempat tidur mereka, dan pukullah mereka. Kemudian jika mereka mentaatimu, Maka janganlah kamu mencari-cari jalan untuk menyusahkannya. Sesungguhnya Allah Maha Tinggi lagi Maha besar.

d. Menghormati dan Mengasihi Kedua Ibu Bapak

Perkawinan bukanlah semata-mata menghubungkan antara kehidupan kedua pasangan tetapi ia juga melibatkan seluruh kehidupan keluarga kedua belah pihak, terutamanya hubungan terhadap ibu bapak kedua pasangan. Oleh itu, pasangan yang ingin membina sebuah keluarga sakinah seharusnya tidak menepikan ibu bapak dalam urusan pemilihan jodoh, terutamanya anak lelaki. Anak lelaki perlu mendapat restu kedua ibu bapaknya karena perkawinan tidak akan memutuskan tanggungjawabnya terhadap kedua ibu bapaknya. Selain itu, pasangan juga perlu mengasihi ibu bapak supaya mendapat keberkatan untuk mencapai kebahagiaan dalam berumahtangga.

Firman Allah SWT yang menerangkan kewajiban anak kepada ibu bapaknya dalam Surah al-Ankabut ayat 8 yang terjemahannya sebagai berikut:

Dan kami wajibkan manusia (berbuat) kebaikan kepadadua orang ibu- bapanya. dan jika keduanya memaksamu untuk mempersekutukan Aku dengan sesuatu yang tidak ada pengetahuanmu tentang itu, maka janganlah kamu mengikuti keduanya. Hanya kepada-Ku-lah kembalimu, lalu Aku khabarkan kepadamu apa yang Telah kamu kerjakan.

e. Menjaga Hubungan Kerabat dan Ipar

Antara tujuan ikatan perkawinan ialah untuk menyambung hubungan 
keluarga kedua belah pihak tua dalam mendidik anaknya termasuk saudara ipar kedua belah misalnya anak dibesarkan dengan pihak dan kerabat-kerabatnya. rasa kasih sayang, penuh perhatian. Karena biasanya masalah seperti c. Faktor Sosial budaya dan spiritual perceraian timbul disebabkan kerenggangan hubungan dengan kerabat dan ipar.

\section{Faktor dan Prinsip Keluarga Sakinah}

Menurut Dadang Hawari dalam buku "Meniti di atas Sunnah menggapai Keluarga Sakinah” tumbuh kembang anak dipengaruhi oleh empat faktor yang saling berinteraksi satu sama lain yaitu:

a. Faktor organo biologik

Faktor organo biologik misalnya perkembangan mental intelektual dan mental emosional banyak ditentukan sejauh mana perkembangan otak dan kondisi fisik. Hal ini juga akan dipengaruhi bagaimanakah asupan gizi yang diperoleh anak, bila gizi baik, maka pertumbuhan otak dan fisik akan optimal.

b. Faktor Psiko-edukatif

Faktor Psiko-edukatif yaitu tumbuh kembang anak akan dipengaruhi oleh sikap dan kepribadian orang
Faktor sosial budaya penting bagi tumbuh kembang anak karena dalam proses pembentukan kepribadian anak dipengaruhi juga oleh budaya-budaya yang ada atau budaya dari luar. Oleh karena itu, orag tua harus bisa memperhatikan keluarganya supaya tidak terbawa arus oleh budaya yang negatif sehingga akan merusak anak. Betapapun derasnya budaya masuk ke dalam kehidupan saat ini, bila anak telah dibentengi oleh agama, maka anak akan bisa menyaringnya. Oleh karena itu, pendidikan spiritual (agama) sangatlah penting bagi anak.

\section{Sedangkan Prinsip-prinsip}

Keluarga Sakinah sebagaimana uraian berikut ini:

\section{a. Komitmen}

Hukum angsa adalah komitmen dan prioritas, sejauh angsa terbang selalu kembali ke kandang bersama keluarga dan mereka memprioritaskan anak-anak dengan 
ungkapan cinta yang lengkap setiap hari untuk menjadikan dengan menyentuhkan kepala anakanaknya. Seperti angsa kita harus memahami bahwa komitmen merupakan ungkapan cinta yang paling lengkap. Memuji kepiting secara insting akan menarik ke bawah bila ada kepiting lain yang mencoba mendahuluinya. Keluarga harus mencari cara untuk membangun kepercayaan diri anakanak kita dengan selalu memuji, dan bukan menyepelekan melalui kritik yang terus menerus. Keluarga harus mendorong anak-anak untuk maju melampaui orang tuanya.

b. Komunikasi

Ikan paus selalu komunikasi dengan keluarga walaupun jauh di laut lepas, nyanyian ikan betina digunakan untuk memanggil anakanaknya. Seperti ikan paus keluarga harus berusaha berkomunikasi secara konstan, kita seharusnya mendengarkan satu sama lain bukan saling mengganggu.

c. Konsisten

Kura-kura binatang berjalan lambat dapat mengalahkan kelinci karena ia berjalan dengan konsisten. Seperti kura-kura kita harus tetap bangkit keluarga kita lebih baik dan saling mencintai.

\section{d. Disiplin}

Belalai gajah bisa lunak ketika menimang dan membimbing anaknya, tapi bisa jadi kuat/keras ketika menghalau rintangan yang menghalanginya. Gajah punya sensitivitas, kelembutan dan disiplin yang tinggi.dalam keluarga marilah kita mencoba menjadi lunak dan baik terhadap satu sama lain, tapi benar-benar tegas dalam hal menjaga aturan.

e. Rasa Aman

Pohon kayu merah adalah makhluk hidup tertinggi di bumi, mereka tumbuh dalam semak dengan akar saling terkait seolah berpegangan tangan. Seperti kayu merah kita harus tumbuh bersama dan semakin dekat satu sama lain sehingga menimbulkan rasa aman pada anak dan keluarga.

f. Tanggung Jawab

Hukum yang diadopsi dari beruang adalah tanggungjawab, yaitu mengambil tanggungjawab penuh dan lengkap bagi keluarga dan semua anak. Memprioritaskan peran 
pengasuhan, memberi teladan dan berharap mereka menerima tanggungjawab. Anak dilatih sejak kecil untuk membantu pekerjaan rumah supaya terbiasa melaksanakan pekerjaan dengan penuh rasa tanggungjawab.

g. Kesadaran

Katak berdarah dingin dia suka berada di lingkungan yang bersuhu hangat, kadang dia tidak menyadari kalau suhu semakin panas yang akhirnya ia mati terendam karena tertidur. Keluarga harus menanamkan kesadaran kepada anak-anak bahwa semua situasi tidak sama dan kita harus memahami perbedaan.

h. Kebebasan

Jika kutu disimpan dalam kotak tertutup, dia bisa melompat sejauh tutup kotak itu, meskipun tutupnya dibuka kutu hanya bisa melompat pada ketinggian tertentu. Hukum kebebasan bagi anak adalah membiarkan anak-anak bebas, dan mampu mengembangkan potensi mereka sejauh mungkin.

\section{KESIMPULAN}

1. Keluarga adalah satu institusi sosial karena keluarga menjadi penentu utama tentang apa jenis warga masyarakat. Apabila keluarga kukuh, maka masyarakat akan bersih dan kukuh. Namun apabila rapuh, maka rapuhlah masyarakat. Begitu pentingnya keluarga dalam menentukan kualitas masyarakat, sehingga dalam pembentukan sebuah keluarga harus benar-benar mengetahui pilar-pilar membangun sebuah keluarga.

2. Mewujudkan keluarga sakinah adalah dambaan setiap manusia. keluarga sakinah ialah kondisi keluarga yang sangat ideal yang terbentuk berlandaskan Al-Quran dan Sunnah untuk mencapai kebahagiaan di dunia dan di akhirat. Membangun keluarga sakinah tidaklah mudah, banyak yang mengalami kesulitan.

3. Prinsip-prinsip dalam membentuk keluarga bahagia, antara lain, Komitmen, Komunikasi, Konsisten, Disiplin, Rasa Aman, Tanggung Jawab, Kesadaran, Kebebasan.

4. Ikhtiar menuju keluarga sakinah, perlu perjuangan yang cukup berat. 
Oleh karena itu, perlu dimulai dengan pendidikan pra nikah, untuk memahami urgensi keluarga, fungsi dan peran keluarga, tugas dan tanggungjawab keluarga, memahami ciri-ciri keluarga sakinah, serta memahai faktorfaktor pembentukan keluarga sakinah kepada anak usia pra nikah, sebab mereka adalah calon pemimpin masa depan yang akan menentukan ke arah mana mereka akan membawa masyarakatnya.

\section{DAFTAR PUSTAKA}

Al-Qur'an dan Terjemahannya. Departemen Agama RI. Semarang; CV. As-Syifa': t.th

Al-Jamy, Muhammad Aman bin Ali. Tatanan Keluarga Dalam Islam. Cet.I; Ramdanai, 1987

Asrori, A.Ma'ruf dan Mas'ud Mubin. Merawat Cinta Kasih Suami Istri. Cet.III; Surabaya: Miftah, 1998

Dachlan, Ny.Aisyah. Membina Rumah Tangga. Penerbit Jamunu, 1969

Hamka. Kedudukan Perempuan Dalam Islam. Jakarta; Penerbit Pustaka Panjimas, 1996

Lama Bawa, Dahlan, dkk. Meniti Diatas Sunnah Menggapai Keluarga Sakinah. Cet.III.
Makassar; LSQ Makassar, tahun 2015

PP. Muhammadiyah. Pedoman Hidup Islami (PHI) Warga Muhammadiyah. 2005

Ridhawi, Sayyid Muhammad. Perkawinan Moral dan Seks Dalam Islam. Cet. I; Penerbit Lantera: 1994 